\title{
Study on status and solution to improve the ventilation system of Quang Hanh coal mine
}

\author{
Chi Van Dao ${ }^{1,}$, Ha Xuan Tran ${ }^{2}$ \\ 1 Faculty of Mining, Hanoi University of Mining and Geology, Vietnam \\ 2 Vietnam Association of Mining Science and Technology, Vietnam
}

\begin{abstract}
ARTICLE INFO
ABSTRACT

Article history:

Received 25th Apr. 2020

Revised 29th July 2020

Accepted 31stAug. 2020

Keywords:

Air leakage,

Air ventilation,

Face,

Impeller angle,

Quang Hanh.

Quang Hanh coal mine is currently operating at two areas with 11 longwalls having the annual production of 1.5 million tonnes. In recent years, the mine has used 4 conjugate fan stations for air ventilation. To assess the quality of ventilation operation at the Quang Hanh coal mine, the paper surveyed the ventilation quality at longwall faces, roadway faces, ventilation works and main fans. The results show that the ventilation at longwall and roadway faces basically satisfies the requirements. However, in some areas, the fresh air has not been sufficiently supplied, the temparature and humidity are high, the air leakage is serious, and the total intake air lacks an amount of $26.4 \mathrm{~m}^{3} / \mathrm{s}$ $(8 \%)$. Based on these the findings, the paper the proposes proper solutions to the air ventilation system at the Quang Hanh coal mine in the near future.
\end{abstract}

Copyright @ 2020 Hanoi University of Mining and Geology. All rights reserved.

${ }^{*}$ Corresponding author

E-mail: daovanchi@humg.edu.vn

DOI: 10.46326/JMES.2020.61(4).12 


\title{
Tạp chí Khoa học Kỹ thuật Mỏ - Địa chất
}

Trang điện tử: http://tapchi.humg.edu.vn

\section{Nghiên cứu hiện trạng và đề xuất các giải pháp hoàn thiện hệ thống thông gió mỏ than Quang Hanh}

\author{
Đào Văn Chi 1,*, Trần Xuân Hà ${ }^{2}$ \\ ${ }^{1}$ Khoa Mỏ, Trường Đại học Mỏ - Địa chất, Việt Nam \\ ${ }^{2}$ Hội Khoa học và Công nghệ Mỏ, Việt Nam
}

THÔNGTINBÀI BÁO

\section{TÓMTẮT}

Quá trình:

Nhận bài 25/ 04/ 2020

Sửa xong 29/07/2020

Chấp nhận đăng 31/ 8/ 2020

Tù khóa:

Góc lắp cánh,

Lò chợ,

Quang Hanh,

Rò gió,

Thông gió.
Mỏ than Quang Hanh hiện đang khai thác ở hai khu vực với 11 lò chộ, công suất 1,5 triệu tấn/năm. Trong nhũ̃ng năm qua, mỏ sủ dụng 04 trạm quạt liên hợp với nhau để thông gió. Để đánh giá chất lượng thông gió của mỏ than Quang Hanh, bài báo tiến hành khảo sát đánh giá hiện trạng chất lượng thông gió các lò chợ, các gương lò chuẩn bị, các công trình thông gió và đánh gia chế độ làm viếc các trạm quạt gió chính. Kết quả cho thấy chất lương thông gió của các lò chợ và lò chuẩn bi cơ bản đáp ứng yêu cẩu, tuy nhiên ở một số khu vực lượng gió cung cấp chưa đủ, nhiệt độ và độ ẩm còn khá cao, mức độ rò gió còn quá lớn, lưu lượng gió chung cần đưa vào mỏ còn thiếu 26,4 $\mathrm{m}^{3} / \mathrm{s}(8 \%)$. Trên cơ sở đó, bài báo đề xuất các giải pháp thông gió hợ lý của Công ty than Quang Hanh trong thời gian tới.

C 2020 Trường Đại học Mỏ - Địa chất. Tất cả các quyền được bảo đảm.

\section{Hiện trạng khai thác của mỏ than Quang Hanh}

Mỏ than Quang Hanh chia làm hai khu chính bao gồm khu cụm vỉa $4 \div 7$ và khu cụm vỉa $7 \div 17$. Hai khu này đã liên thông toàn bộ với nhau dưới mức -175 m. Năm 2019 mỏ than Quang Hanh đang khai thác 11 lò chợ dài với công suất 1,5 triệu tấn/năm. Các lò chợ được khai thác chủ yếu bằng công nghệ khoan nổ mìn, chống lò chợ chủ yếu bằng giá thủy lực XDY, ZH, giá di động, giàn mềm ZRY, giá liên kết xích, giá khung. Duy nhất trong

\footnotetext{
*Tác giả liên hệ

E-mail: daovanchi@humg.edu.vn

DOI: 10.46326/JMES.2020.61(4).12
}

mỏ chỉ có 1 lò chợ CGH đồng bộ. Để đảm bảo thông gió, mỏ sử dụng 04 trạm quạt do Trung Quốc sản xuất để hút liên hợp đặt tại các cánh của từng khu khai thác (Vương Đức Minh, 2007; Trương Quốc Quyền, 1999), trong đó bao gồm (Kế hoạch thông gió quý 3,2019 ):

- Trạm quạt FBCDZ-No-22 đặt tại rãnh gió mức +35 m dùng đề thông gió cho khu Trung tâm, tây bắc cụm vỉa $7 \div 17$.

- Trạm quạt FBCDZ-No-22 đặt tại rãnh gió mức +30 m dùng đề thông gió cho khu Trung tâm, đông nam cụm vỉa $4 \div 7$.

- Trạm quạt FBCDZ-No-27 đặt tại rãnh gió mức +17 m dùng đề thông gió cho khu Trung tâm, đông bắc cụm vỉa $7 \div 17$.

- Trạm quạt FBCDZ-No-14 đặt tại rãnh gió mức +27 m dùng để thông gió cho khu Trung tâm cụm 
vỉa $7 \div 17$. Tại đây hiện lắp đặt 04 quạt FBCDZ1 No14.

\section{2. Đánh giá chất lượng thông gió của mỏ than Quang Hanh}

\section{1. Đánh giá chất lượng thông gió của các lò chơ}

Để đánh giá chất lượng thông gió các lò chợ của mỏ than Quang Hanh, nhóm tác giả tiến hành khảo sát đo đạc các thông số nhiệt độ, độ ẩm, tốc độ gió,... Do diện tích của khu mỏ quá lớn không thể hiện rõ được vị trí của 12 lò chợ, vì vậy vị trí các điểm đo được thể hiện minh họa trên sơ đồ Hình 1 của lò chợ Trung tâm 15-21 mức $-110 \div 60 \mathrm{~m}$ cánh Tây (Trung tâm KHCN Mỏ và môi trường, 2019; kế hoạc thông gió quý III, 2019; QCVN 01/2011/BCT). Kết quả đo đạc thể hiện trong Bảng 1 và 2 .

\subsubsection{Về hướng gió sạch đi trong lò chợ}

Các lò chợ đang tiến hành khai thác ở mỏ đều thuộc loại lò chợ dài và hướng gió đi trong lò chợ đều đi từ dưới lên trên, nghĩa là từ lò dọc vỉa thông gió đi lên lò dọc vỉa vận tải.

Riêng ở lò chợ khu Nam 7.1, mức $-100 \div 50 \mathrm{~m}$, vì hiện tại trạm quạt, mức $+22 \mathrm{~m}$ đã di chuyển cho nên hướng gió đi từ trên xuống dưới.

Vì vậy, có thể khẳng định rằng hướng gió đi trong các lò chợ phần lớn là phù hợp với qui định

Bảng 1. Lưu lượng gió đi qua các lò chợ.

\begin{tabular}{|c|c|c|c|c|c|c|c|c|}
\hline & \multirow{2}{*}{ Tên lò chợ } & \multicolumn{2}{|c|}{$\begin{array}{c}\text { Lượng gió cần theo } \\
\text { tính toán, } \mathrm{m}^{3} / \mathrm{s}\end{array}$} & \multicolumn{2}{|c|}{$\begin{array}{l}\text { Lượng gió khi đo } \\
\text { đạc, } \mathrm{m}^{3} / \mathrm{s}\end{array}$} & \multicolumn{3}{|c|}{ Tốc độ gió m/s } \\
\hline & & Qmin & Qmax & Thực tế & Đánh giá & $\begin{array}{l}\text { Thực } \\
\text { tế }\end{array}$ & $\begin{array}{l}\text { Cho } \\
\text { phép }\end{array}$ & $\begin{array}{l}\text { Đánh } \\
\text { giá }\end{array}$ \\
\hline 1 & Lò chợ trung tâm 11-3 mức -175 -120 & 4,88 & 11,80 & 9,6 & Đạt & 2,4 & $0,25 \div 4$ & Đạt \\
\hline 2 & Lò chợ CGHT.T.7-10 mức -120 -115 & 5,09 & 15,15 & 10,1 & Đạt & 1,8 & $0,25 \div 4$ & Đạt \\
\hline 3 & Lò chợ TT7-3 mức -110 -90. & 4,48 & 9,81 & 4,70 & Thiếu & 1,16 & $0,25 \div 4$ & Đạt \\
\hline 4 & Lò chợ TT7-2 mức -110 -60. & 3,39 & 9,21 & 3,88 & Thiếu & 0,99 & $0,25 \div 4$ & Đạt \\
\hline 5 & 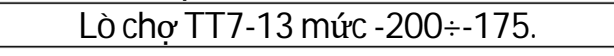 & 4,47 & 10,94 & 4,40 & Thiếu & 1,10 & $0,25 \div 4$ & Đạt \\
\hline 6 & 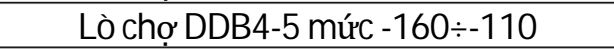 & 4,47 & 11,25 & 5,61 & Đạt & 1,40 & $0,25 \div 4$ & Đạt \\
\hline 7 & 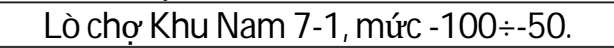 & 4,00 & 9,23 & 5,40 & Đạt & 1,35 & $0,25 \div 4$ & Đạt \\
\hline 8 & Lò chợ TT 15-21 mức-110 -60 cánh Tây & 3,15 & 9,45 & 3,60 & Đạt & 0,90 & $0,25 \div 4$ & Đạt \\
\hline 9 & Lò chợ TT 14-13 mức-160 -105 & 4,47 & 10,30 & 4,40 & Thiếu & 1,10 & $0,25 \div 4$ & Đạt \\
\hline 10 & Lò chợ TT 17-3 mức-105 -90 & 3,68 & 8,48 & 4,20 & Đạt & 1,05 & $0,25 \div 4$ & Đạt \\
\hline 11 & Lò chợ giàn ZRYKDDN7-1 mức 120 -50 & 3,15 & 9,22 & 4,26 & Đạt & 1,06 & $0,25 \div 4$ & Đạt \\
\hline 12 & Lò chợ CGHTT7-12 mức-160 ×-125 & 5,90 & 13,62 & 9,10 & Đạt & 1,62 & $0,25 \div 4$ & Đạt \\
\hline
\end{tabular}

Bảng 2. Chất lượng thông gió các lò chợ.

\begin{tabular}{|c|c|c|c|c|c|c|c|c|}
\hline \multirow{3}{*}{$\mathrm{TT}$} & \multirow{3}{*}{ Tên lò chợ } & \multicolumn{4}{|c|}{ Điều kiện vi khí hậu } & \multicolumn{3}{|c|}{ Hàm lượng các khí } \\
\hline & & \multicolumn{2}{|c|}{ Nhiệt độ, ${ }^{\circ} \mathrm{C}$} & \multirow{2}{*}{$\begin{array}{c}\text { Độ ẩm } \\
\%\end{array}$} & \multirow{2}{*}{ Đánh giá } & \multirow{2}{*}{$\mathrm{CO} 2, \%$} & \multirow{2}{*}{$\mathrm{CH} 4, \%$} & \multirow{2}{*}{ Đánh giá } \\
\hline & & Khô & Ướt & & & & & \\
\hline 1 & 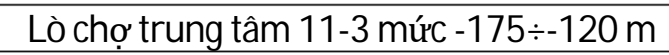 & 28,1 & 27,8 & 92 & Đạt & 0,2 & 0,26 & Đạt \\
\hline 2 & 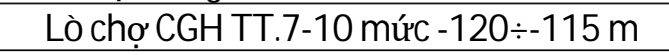 & 28,5 & 28,0 & 92 & Đạt & 0,2 & 0,45 & Đạt \\
\hline 3 & Lò chợ CGHTT7-12 mức -160 -105 m & 29,6 & 28,8 & 93 & Đạt & 0,25 & 0,47 & Đạt \\
\hline 4 & Lò chợ TT7-3, mức -110 -90 m & 29,7 & 28,9 & 95 & Đạt & 0,2 & 0,48 & Đạt \\
\hline 5 & Lò chợ TT7-2, mức-110 $\div 60 \mathrm{~m}$ & 29,7 & 28,7 & 94 & Đạt & 0,2 & 0,48 & Đạt \\
\hline 6 & 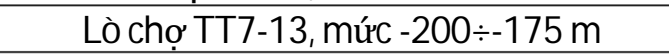 & 22,5 & 28,5 & 92 & Đạt & 0,25 & 0,48 & Đạt \\
\hline 7 & Lò chợ DDB4-5 mức-160 -110 m & 28,8 & 27,9 & 93 & Đạt & 0,23 & 0,42 & Đạt \\
\hline 8 & Lò chợ khu Nam 7-1, mức -100 -50 m & 29,1 & 28,7 & 94 & Đạt & 0,24 & 0,44 & Đạt \\
\hline 9 & Lò chợ TT 14-13 mức -160 —-105 m & 28,2 & 27,9 & 91 & Đạt & 0,25 & 0,34 & Đạt \\
\hline 10 & Lò chợ TT 17-3 mức -105—90 m & 27,3 & 26,9 & 92 & Đạt & 0,23 & 0,28 & Đạt \\
\hline 11 & Lò chợ giàn ZRYKDDN7-1 mức 120 -50 m & 28,8 & 28,1 & 93 & Đạt & 0,22 & 0,37 & Đạt \\
\hline 12 & Lò chợ CGH TT7-12 mức-160 -125 m & 27,6 & 29,2 & 92 & Đạt & 0,22 & 0,41 & Đạt \\
\hline
\end{tabular}




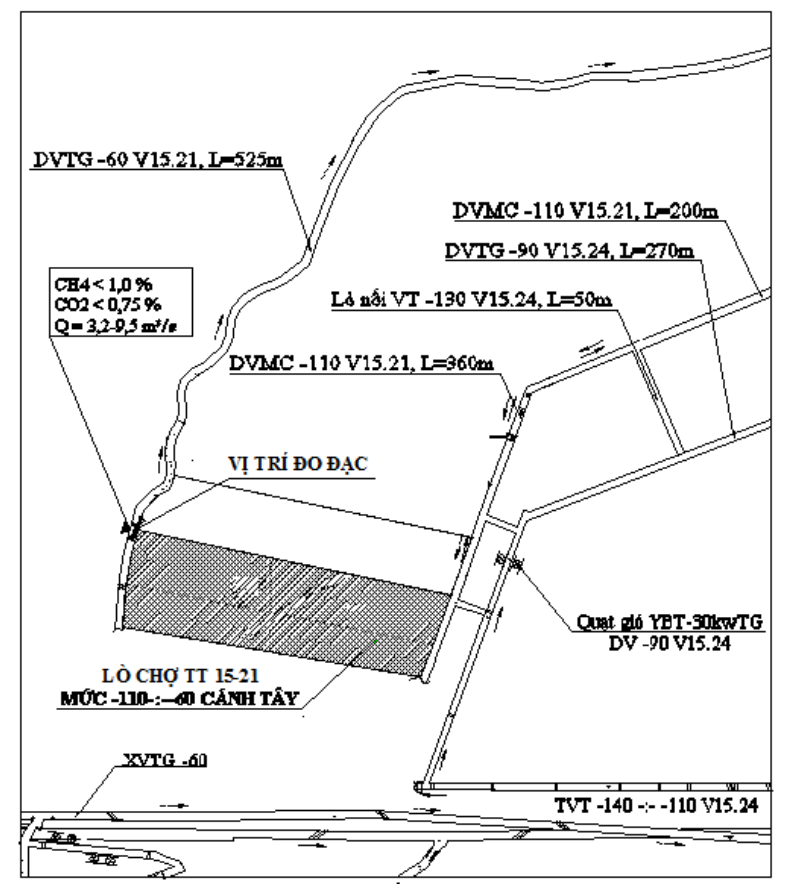

Hình 1. Sơ đồ đo đạc điều kiện vi khí hậu tại lò

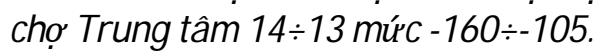

hiện hành theo QCVN 01/2011/ BCT (Quy chuẩn kỹ thuật quốc gia, 2011).

\subsubsection{Về lượng gió đi qua các lò chợ}

Kết quả đo đạc xác định lượng gió đi qua lò chợ so với lượng gió cần theo tính toán được trình bày trong Bảng 1, còn hiệu quả (chất lượng) thông gió cho các lò chợ được ghi trong Bảng 2 (Đào Văn Chi, 2017).

Phân tích các số hiệu ghi trong các Bảng 1 và 2 , có thể rút ra một số nhận xét sau:

- Về lưu lượng gió đi đến các lò chợ thì trong số 12 lò chợ có 8 lò chợ có lượng gió thực tế đạt yêu cầu và 4 lò chợ thiếu gió.

- Vê điều kiện vi khí hậu ở các lò chợ thì có thể đánh giá chung là chấp nhận được, song nhìn chung nhiệt độ và độ ẩm còn khá cao.

- Về hàm lượng các khí $\mathrm{CO}_{2}$ và $\mathrm{CH}_{4}$, kết quả quan trắc thường xuyên của mỏ cho thấy các hàm lượng này đều nằm dưới giới hạn tối đa cho phép.

Đánh giá chung, chất lượng thông gió của các lò chợ nhìn chung chấp nhận được.

\subsection{Kiểm định chất lượng thông gió cho các gương lò chuẩn bị}

Vào thời điểm tháng 9/2019, toàn mỏ tiến hành thi công đồng thời trên 40 gương lò chuẩn bị (Trung tâm KHCN Mỏ và Môi trường, 2019).
Trong số đó Công ty Xây lắp mỏ đào 11 đường lò, công ty ASEAN đào 9 đường lò, còn lại do Công ty than Quang Hanh đảm nhiệm. Để thông gió cho các gương lò chuẩn bị, mỏ sử dụng các quạt gió cục bộ do Trung Quốc sản xuất. Để kiểm định chất lượng thông gió cho các gương lò chuẩn bị, tiến hành đo đạc chất lượng thông gió của các gương lò chuẩn bị (thiết bị, vị trí và phương pháp đo theo quy định của QCVN01/BCT/2011), từ đó rút ra những nhận xét sau:

- Phương pháp thông gió đẩy được sử dụng ở các gương lò chuẩn bị là phương pháp thông gió hoàn toàn hợp lý (Trần Xuân Hà, 2014; Đào Văn Chi, 2017).

- Chất lượng thông gió cho các gương lò chuẩn bị nhìn chung đáp ứng yêu cầu.

- Chất lượng đường ống gió ở một số đường lò đào chưa đảm bảo, vì còn bị thủng.

- Điều kiện vi khí hậu ở một số gương lò chuẩn bị chưa đáp ứng nhu cầu vì nhiệt độ còn khá cao (trên $30^{\circ} \mathrm{C}$ ) và độ ẩm lớn $(94 \div 95 \%)$.

\subsection{Kiểm định các công trình thông gió của mỏ}

Các công trình thông gió trong mỏ được bố trí là các cửa gió. Trong toàn mỏ thường xuyên có tới 50 cửa. Các cửa này chủ yếu được chế tạo từ gỗ có khung sắt. Qua quá trình khảo sát thực tế một số cửa gió trong mỏ và các số liệu thống kê đánh giá chất lượng tất cả các cửa gió trong mỏ, chúng tôi có một số nhận xét sau:

- Việc bố trí các cửa gió và vị trí đặt các cửa gió nhìn chung là hợp lý.

- Vật liệu xây dựng các công trình thông gió chủ yếu là gỗ, khung cửa bằng ván be, phủ vải bạt, cửa gió làm bằng sắt hoặc gỗ tùy theo vị trí đặt cửa. Hâu hết các cửa gió đều không đủ độ kín khít dẫn đến rò gió lớn. Đây là nguyên nhân chính dẫn đến thiếu gió cung cấp cho nhiều hộ tiêu thụ.

- Việc quản lý đóng mở cửa gió còn chưa tốt, nhiều cửa gió thường phải đóng kín nhưng không được đóng dẫn đến tổn thất gió lớn.

- Lượng gió rò lớn đáng kể là ở các trạm quạt. Ví dụ:

+Tại cụm vỉa 4\%7: trạm quạt mức $+30 \mathrm{~m}$ tổng lượng gió sạch bị thất thoát qua các cửa gió và tường chắn là 20,3 m³/s, chiếm 30,4\% tổng lượng gió hút qua trạm quạt.

+Tại cụm vỉa $7 \div 17$ : trạm quạt mức $+17 \mathrm{~m}$ tổng lượng gió sạch bị thất thoát qua các cửa gió 
Bảng 3. Chế độ làm việc của các quạt gió chính.

\begin{tabular}{|c|c|c|c|c|c|c|c|c|c|c|}
\hline \multirow{2}{*}{ TT } & \multirow[t]{2}{*}{$\begin{array}{l}\text { Tên trạm quạt } \\
\text { gió }\end{array}$} & \multicolumn{2}{|c|}{$\begin{array}{c}\text { Chế độ làm việc } \\
\text { theo yêu cầu }\end{array}$} & \multicolumn{2}{|c|}{$\begin{array}{l}\text { Chế độ làm } \\
\text { việc theo lý } \\
\text { thuyết }\end{array}$} & \multicolumn{2}{|c|}{$\begin{array}{l}\text { Chế độ làm } \\
\text { việc thực tế }\end{array}$} & \multicolumn{2}{|c|}{ Kết quả đo } & \multirow[t]{2}{*}{ Đánh giá } \\
\hline & & hq, Pa & $\begin{array}{c}\mathrm{Qq}, \\
\mathrm{m}^{3} / \mathrm{s}\end{array}$ & hq, $\mathrm{Pa}$ & $\begin{array}{c}\mathrm{Qq}, \\
\mathrm{m}^{3} / \mathrm{s}\end{array}$ & hq, Pa & $\begin{array}{c}\mathrm{Qq}, \\
\mathrm{m}^{3} / \mathrm{s}\end{array}$ & hq, Pa & $\begin{array}{l}\mathrm{Qq}, \\
\mathrm{m}^{3} / \mathrm{s}\end{array}$ & \\
\hline 1 & $\begin{array}{c}\text { Trạm quat } \\
\text { FBDCZ-No27, } \\
\text { mức +17 }\end{array}$ & 1119,61 & 84,99 & 2400 & 118,0 & 2050 & 98 & 2370 & 82,7 & Đáp ứng yêu cầu \\
\hline 2 & $\begin{array}{l}\text { Trạm quat } \\
\text { FBDCZ-No14, } \\
\text { mức }+27\end{array}$ & 270 & 38,31 & 220 & 33 & 620 & 52 & 550 & 36,7 & $\begin{array}{l}02 \text { quạt làm việc } \\
\text { đồng thời có khả } \\
\text { năng đáp ứngyêu } \\
\text { cầu }\end{array}$ \\
\hline 3 & $\begin{array}{l}\text { Trạm quat } \\
\text { FBDCZ-No22, } \\
\text { mức }+30\end{array}$ & 2336 & 86,73 & 1850 & 74 & 1750 & 73 & 2060 & 76,8 & $\begin{array}{l}\text { Năng lực còn kém } \\
\text { so với yêu cầu }\end{array}$ \\
\hline 4 & $\begin{array}{l}\text { Trạm quat } \\
\text { FBDCZ-No22, } \\
\text { mức +35 }\end{array}$ & 1800,31 & 84,03 & 1650 & 80 & 1505 & 77,5 & 1980 & 72 & $\begin{array}{l}\text { Năng lực chưa đáp } \\
\text { úng yêu cầu }\end{array}$ \\
\hline 5 & Tổng cộng & & 294,6 & & 305 & & 300,5 & & 268,2 & \\
\hline
\end{tabular}

và tường chắn là $27,7 \mathrm{~m} 3 / \mathrm{s}$, chiếm $31 \%$ tổng lượng gió hút qua trạm quạt. Trạm quạt mức +35 $\mathrm{m}$ tổng lượng gió sạch bị thất thoát qua các cửa gió và tường chắn là $15,8 \mathrm{~m} 3 / \mathrm{s}$, chiếm $65,8 \%$ tổng lượng gió hút qua trạm quạt.

- Tại lò xuyên vỉa thông gió mức -50 m có đặt 1 cửa gố tường gỗ để điều tiết gió, nhưng do tàu goòng đi lại nhiều (đặc biệt đầu ca) nên cưa thường bị mở gây ảnh hưởng trực tiếp đến lượng gió đi qua lò chợ vỉa 10.

- Trên nhiều đoạn đường lò có các lò không còn hoạt động (đã xây tường chắn bịt kín) nhưng vẫn còn lượng gió rò qua các tường chắn đi vào đường lò. Cụ thể, tại ngầm thông gió mức $-50 \div+35 \mathrm{~m}$ lượng gió vào là $16,2 \mathrm{~m}^{3} / \mathrm{s}$, lượng gió ra là 26,9 $\mathrm{m}^{3} / \mathrm{s}$. Lưu lượng gió tổn thất qua các tường chắn làm giảm lượng gió cung cấp cho các hộ tiêu thụ.

\section{4. Đánh giá hiện trạng các đường lò}

Các đường lò trong mỏ đa số được chống bằng vì sắt $\mathrm{SPV}$, nhìn chung duy trì được tiết diện, đường lò khá thông thoáng, không gây khó khăn cho công tác thông gió và đi lại, vận tải. Tuy vậy, cũng còn một vài đoạn lò thông gió (đầu một số lò chợ) do áp lực mỏ, cho nên bị nén ép thu nhỏ tiết diện.

\section{5. Đánh giá chế độ làm việc của các quạt gió chính}

Chế độ làm việc thực tế và theo tính toán được trình bày trong Bảng 3 .

Phân tích các số liệu trình bày trong Bảng 3 có thể rút ra những nhận xét sau:

- Trong số 4 trạm quạt gió chính hoạt động thì 2 trạm quạt (quạt FBDCZ-No27, mức +17 m và quạt FBDCZ-No14, mức +27 m) có khả năng đáp ưng nhu cầu. Còn 2 trạm còn lại (FBDCZ-No22 tại mức +30 mvà mức $+35 \mathrm{~m}$ ) chưa đáp ứng yêu cầu. Nhìn chung lượng gió còn thiếu trên dưới $10 \mathrm{~m}^{3} / \mathrm{s}$ (xem Bảng 3).

- Các quạt gió đều đang làm việc ở góc lắp cánh nhỏ: $0^{\circ}$ và $-5^{\circ}$. Song việc tăng góc lắp cánh của các quạt gió này sẽ không dễ dàng thực hiện được vì rất khó đảm bảo trạng thái cân bằng động.

\section{3. Đề xuất các giải pháp hoàn thiện hệ thống thông gió mỏ than Quang Hanh}

Các giải pháp hoàn thiện hệ thống thông gió chủ yếu cần thực hiện nhanh chóng bao gồm:

- Chống rò gió tại các cửa lắp đặt trạm quạt gió chính:

Tại các cửa lò đặt các trạm quạt gió chính, cần cải tạo, hoàn thiện các cánh cửa và lắp đặt cổng gió, 
nhằm tránh rò gió đến mức tối đa. Cụ thể là các cổng gió tại:

Rãnh gió : $+35 \div 50 \mathrm{~m}$

Rãnh gió : $+30 \div 12 \mathrm{~m}$

Rãnh gió : $+17 \div 50 \mathrm{~m}$

Rãnh gió : $+30 \div+0 \mathrm{~m}$

Chi tiết có ở tài liệu kế hoạch thông gió quý III năm 2019 của mỏ, trong đó hình dáng, vị trí các rãnh gió được kết nối với các trạm quạt được bố trí như ở Hinh 2, 3,4, 5 .

- Cải tạo hoàn thiện, thay thế tất cả các cửa gió kém chất lượng.

Các cửa gió kém chất lượng cần phải thay được trình bày trong Bảng 4.

- Tháo bỏ tất cả các cửa gió hiện không còn vai trò điều chỉnh gió trong mỏ.

- Làm cửa gió tự động ở đoạn lò cần có cửa gió, cần thường xuyên phải đóng, song do phương tiện vận tải thường xuyên qua lại, như cửa gió ở lò nối vận chuyển mức-110 m.

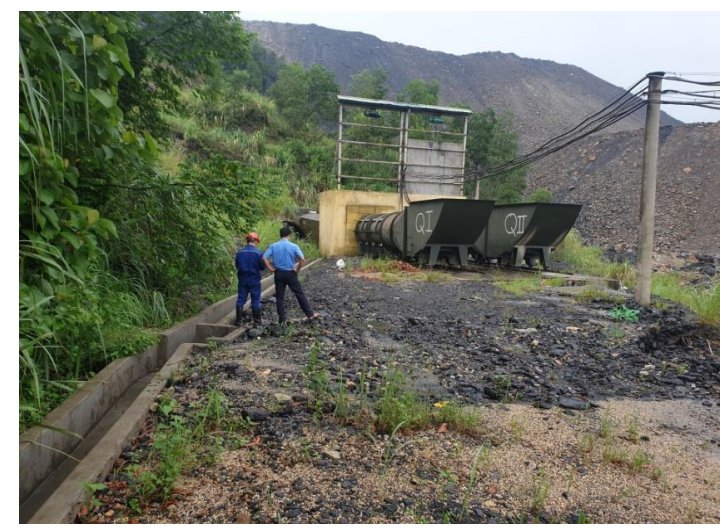

Hình 2. Hình ảnh chung trạm quạt FBDCZ- No22, múc $+35 \mathrm{~m}$

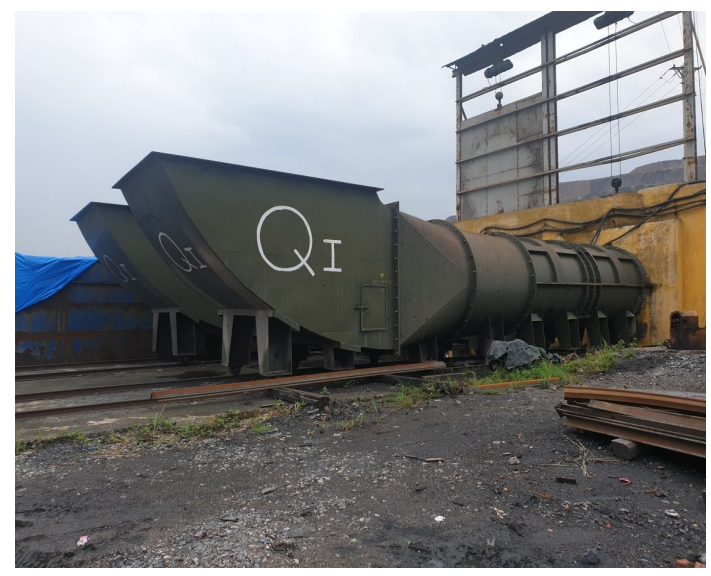

Hình 4. Hình ảnh chung trạm quạt FBCDZ.No 22, múc $+30 \mathrm{~m}$
- Cần bịt kín tất cả các tường chắn để giảm rò gió qua khu vực phá hỏa. Ví dụ: tường chắn ở thượng thông gió mức $-50 /+35$ m hoặc tường chắn ở lò xuyên vỉa đá mức $-50 \mathrm{~m}$.

- Ở các lò chuẩn bị có chiều dài lớn, cần kiểm tra và thay các đoạn ống gió cũ, bị thủng, rò gió nhiều.

- Cân duy trì khoảng cách từ miệng ống gió đến gương lò chuẩn bị trong khoảng $8 \div 10 \mathrm{~m}$ để đảm bảo thông gió gương lò.

- Nhằm đảm bảo yêu cầu về cung cấp gió cho các hộ tiêu thụ gió do các quạt gió FBDCZ-No22 đang làm việc tại mức $+30 \mathrm{~m}$ và $+35 \mathrm{~m}$, cần tăng góc lắp cánh của chúng từ $-5^{\circ}$ lên $0^{\circ}$, để đáp ứng lượng gió lâu dài.

\section{Kết luận}

- Chất lượng thông gió của các lò chợ và lò chuẩn bị cơ bản đáp ứng yêu cầu, ở một số lò chợ

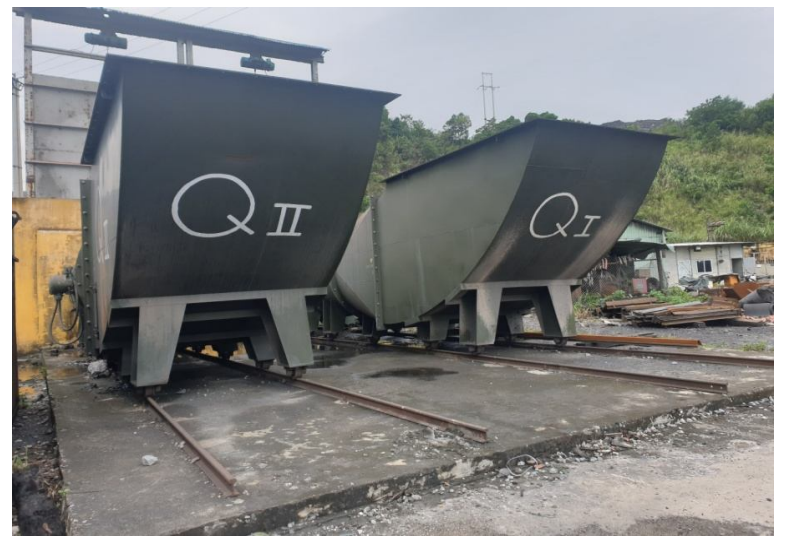

Hình 3. Hình ảnh chung trạm quạt FBDCZ-No27 múc $+17 \mathrm{~m}$

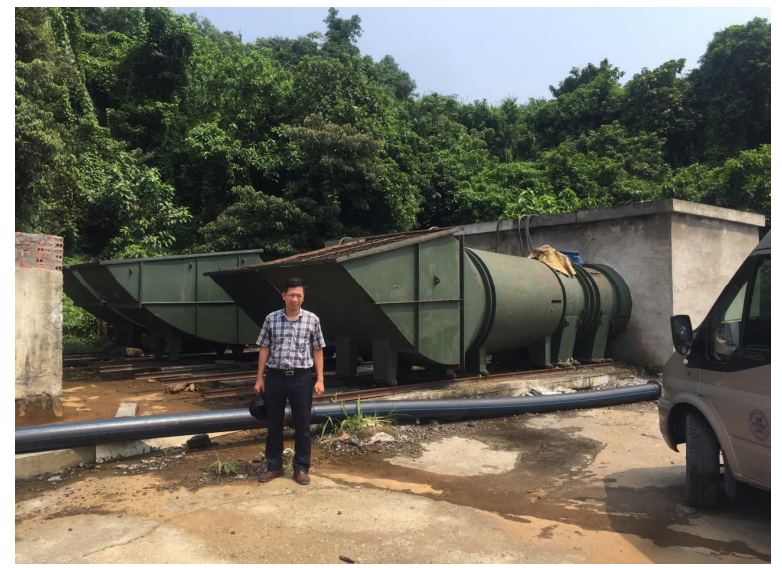

Hình 5. Hình ảnh chung trạm quạt FBDCZ- No14, múc $+27 \mathrm{~m}$ 
Bảng 4. Các của gió cần cải tạo, hoàn thiện.

\begin{tabular}{|c|c|c|c|c|c|}
\hline STT & Công trình & Vị trí & Ký hiệu & Đoạn lò & $\begin{array}{l}\text { Phương án cải tạo, } \\
\text { tháo dơ', đặt mới cửa } \\
\text { gió }\end{array}$ \\
\hline 1 & $\begin{array}{c}\text { Cửa gió } \\
\text { thường đóng }\end{array}$ & Lò XV VT -50 m TT & CG01 & $59-114$ & Cải tạo, làm kín cửa gió \\
\hline 2 & $\begin{array}{c}\text { Cửa gió } \\
\text { thường đóng }\end{array}$ & $\begin{array}{l}\text { Ngầm thông gió -50/-130 } \\
\text { m V7 }\end{array}$ & CG04 & $48-113$ & Cải tạo, làm kín cửa gió \\
\hline 3 & $\begin{array}{c}\text { Cứa gió } \\
\text { thường đóng }\end{array}$ & $\begin{array}{l}\text { Ngầm thông gió -50/-130 } \\
\text { m V7 }\end{array}$ & CG05 & $113-110$ & Cải tạo, làm kín cửa gió \\
\hline 4 & $\begin{array}{c}\text { Cứa gió } \\
\text { thường đóng }\end{array}$ & Lò nối & CG09 & 110-109 & Cải tạo, làm kín cửa gió \\
\hline 5 & $\begin{array}{l}\text { Cửa gió } \\
\text { thường đóng }\end{array}$ & $\begin{array}{c}\text { TTG-130/-110 m LC } \\
\text { KN7.3 }\end{array}$ & CG10 & 106-109 & Cải tạo, làm kín cửa gió \\
\hline 6 & $\begin{array}{c}\text { Cửa gió } \\
\text { thường đóng }\end{array}$ & Ngầm -50/-110 m & CG13 & $64-81$ & Cải tạo, làm kín cửa gió \\
\hline 7 & $\begin{array}{c}\text { Cửa gió } \\
\text { thường đóng }\end{array}$ & $\begin{array}{c}\text { Thượng TG-175/-110 m } \\
\text { V7 }\end{array}$ & CG15 & $22-21$ & Cải tạo, làm kín cửa gió \\
\hline 8 & $\begin{array}{c}\text { Cửa gió } \\
\text { thường đóng }\end{array}$ & $\begin{array}{l}\text { Thượng TG-175/-90 m } \\
\text { V10 }\end{array}$ & CG16 & 130-141 & Cải tạo, làm kín cửa gió \\
\hline 9 & $\begin{array}{c}\text { Cửa gió } \\
\text { thường đóng }\end{array}$ & TTG-160/-110 m V11.2 & CG24 & 209-204 & Cải tạo, làm kín cửa gió \\
\hline 10 & $\begin{array}{c}\text { Cửa gió } \\
\text { thường đóng }\end{array}$ & $\begin{array}{l}\text { Giếng phụ trục tải +27/ - } \\
50 \mathrm{~m}\end{array}$ & CG26 & 123-187 & Cải tạo, làm kín cửa gió \\
\hline 11 & $\begin{array}{c}\text { Cửa gió } \\
\text { thường đóng }\end{array}$ & TTG-175/-70 m V10 & CG31 & 170-171 & Cải tạo, làm kín cửa gió \\
\hline 12 & $\begin{array}{c}\text { Cửa gió } \\
\text { thường đóng }\end{array}$ & TTG-175/-70 m V10 & CG32 & 171-180 & Cải tạo, làm kín cửa gió \\
\hline 13 & $\begin{array}{c}\text { Cửa gió } \\
\text { thường đóng }\end{array}$ & $\begin{array}{c}\text { Thượng VT -175/-130 m } \\
\text { V14.14 }\end{array}$ & CG34 & $217-216$ & Cải tạo, làm kín cửa gió \\
\hline 14 & $\begin{array}{c}\text { Cưa gió } \\
\text { thường đóng }\end{array}$ & $\begin{array}{c}\text { Thượng VT -175/-110 m } \\
\text { LC TT 14.14 }\end{array}$ & CG35 & 218-219 & Cải tạo, làm kín cửa gió \\
\hline 15 & $\begin{array}{l}\text { Cửa gió } \\
\text { thường đóng }\end{array}$ & $\begin{array}{c}\text { TTG -175/ -60 m LC } \\
\text { TT15.9 }\end{array}$ & CG38 & $232-238$ & Cải tạo, làm kín cửa gió \\
\hline 16 & $\begin{array}{c}\text { Cửa gió } \\
\text { thường đóng }\end{array}$ & Rãnh gió +35 m & CG43 & 185-183 & Cải tạo, làm kín cửa gió \\
\hline 17 & $\begin{array}{c}\text { Cửa gió } \\
\text { thường đóng }\end{array}$ & Rãnh gió +20 m & CG44 & $240-241$ & Cải tạo, làm kín cửa gió \\
\hline 18 & $\begin{array}{c}\text { Cửa gió } \\
\text { thường đóng }\end{array}$ & TTG-175/-110 m V13 & CG62 & 160-197 & Cải tạo, làm kín cửa gió \\
\hline 19 & $\begin{array}{c}\text { Cửa gió } \\
\text { thường đóng }\end{array}$ & $\begin{array}{l}\text { Giếng phụ trục tải +27/ - } \\
50 \mathrm{~m}\end{array}$ & CG25 & $121-123$ & $\begin{array}{l}\text { Bỏ cửa, lắp mới cửa sắt } \\
\text { tường gạch }\end{array}$ \\
\hline 20 & $\begin{array}{l}\text { Cửa gió điều } \\
\text { chỉnh }\end{array}$ & Lò XV TT IV & CG17 & 131-132 & $\begin{array}{l}\text { Thay thế bằng cửa điều } \\
\text { chỉnh }\end{array}$ \\
\hline 21 & $\begin{array}{c}\text { Cửa gió } \\
\text { thường đóng }\end{array}$ & Lò DVTG mức -110 m & CG36 & 195-197 & Lắp đặt mới cánh cửa \\
\hline
\end{tabular}


và lò chuẩn bị lượng gió được cung cấp chưa đủ, nhiệt độ và độ ẩm còn khá cao.

- Mức độ rò gió ở các cửa gió còn quá lớn, dần đến lượng gió đến các hộ tiêu thụ gió còn thiếu.

- Chế độ làm việc của các quạt gió chính theo số liệu đo đạc là $268,2 \mathrm{~m}^{3} / \mathrm{s}$, còn theo yêu cầu là $244,6 \mathrm{~m}^{3} / \mathrm{s}$. Như vậy lượng gió chung cần đưa vào mỏ còn thiếu là: $26,4 \mathrm{~m}^{3} / \mathrm{s}(8 \%)$.

Các giải pháp cần áp dụng nhằm nâng cao chất lượng thông gió cho các mỏ bao gồm:

- Cải tạo, hoàn thiện tất cả các cửa gió trong mỏ và ở các trạm quạt để giảm tối đa lượng gió rò.

- Lắp đặt một số cửa gió tự động ở các vị trí có phương tiện vận tải qua lại thường xuyên.

- Nâng góc lắp cánh của các quạt FBDCZ-No22 từ $-5^{\circ}$ lên $0^{\circ}$, nhằm đáp ứng yêu cầu thông gió chung cho mỏ.

Đề nghị công ty Quang Hanh nhanh chóng áp dụng các giải pháp được trình bày ở trên nhằm nẩng cao chất lượng thông gió cho mỏ. Mặt khác, mỏ cũng nên đầu tư lắp đặt hệ thống quan trắc tự động chế độ làm việc của các quạt gió chính.

\section{Tài liệu tham khảo}

Bộ công thương, (2011). "Quy chuẩn kỹ thuật quốc gia về an toàn trong khai thác than hầm lò (QCVN 01:2011/BCT)". Nhà Xuất bản Lao động, Hà Nội.

Trần Xuân Hà, Đặng Vũ Chí, Nguyễn Cao Khải, Nguyễn Văn Thịnh, (2014). "Giáo trình Thông gió mỏ". Nhà xuất bản Khoa học và kỹ thuật, Hà Nội.
Kế hoạch thông gió quý III năm 2019, Phòng Thông gió, Công ty than Quang Hanh -TKV.

Trần Xuân Hà, Đào Văn Chi, Nguyễn Xuân Hoàn, (2016). Các nguyên nhân và biện pháp xử lý cháy ở một số mỏ hầm lò vùng Quảng Ninh, Tạp chí khoa học kỹ thuật Mỏ - Địa chất, số 57. Tr 86-94.

Đào Văn Chi, Lê Quang Phục, Nguyễn Sơn Tùng, (2017). Điều hòa khí hậu trong lò chợ Cơ giới hóa 11-1.15 bằng thiết bị MK-300 ở mỏ than Hà Lầm, Tạp chí khoa học kỹ thuật Mỏ - Địa chất, Tập 58, kỳ 5, Tr 408-413.

Trung tâm KHCN Mỏ và Môi trường, (2019). Báo cáo tổng kết "Khảo sát đánh giá hiện trạng thông gió và đề xuất các giải pháp thông gió hợp lý của Công ty than Quang Hanh".

Vương Đức Minh, (2007). Thông gió và An toàn mỏ (tiếng Trung Quốc). NXB Trường Đại học Mỏ và Công nghệ Trung Quốc, Từ Châu, Giang Tô, Trung Quốc.

Trương Quốc Quyền, (1999). Thông gió và An toàn (tiếng Trung Quốc), NXB Đại học Mỏ và Công nghệ Trung Quốc, Từ Châu, Giang Tô, Trung Quốc 